\title{
Adsorption of Acid Red 18 (AR18) by Activated Carbon from Poplar Wood - A Kinetic and Equilibrium Study
}

\author{
REZA SHOKOOHI, VAHID VATANPOOR ${ }^{\S}$, \\ MANSUOR ZARRABI* and AKRAM VATANI
}

Department of Environmental Health,

Faculty of Public Health, University of Medical Science, Hamadan, Iran.

${ }^{\S}$ Water and Wastewater Treatment Laboratory,

Department of Chemistry, Faculty of Science, University of Tabriz, Iran.

mansor62@gmail.com

Received 10 May 2009; Accepted 5 July 2009

\begin{abstract}
Adsorption process by activated carbon is widely used for removal of dyes. Because of economical limits, activated carbon derived from low cost materials seem to be economical. The aim of this work is preparation of activated carbon from poplar wood and investigation of its ability to removal of (AR18) dye. In this work, we prepared the activated carbon by chemical activation method in electric furnace. In addition we have investigated effect of various parameters such as $\mathrm{pH}$, contact time, dye concentration and adsorbent dosage on dye removal. Langmuir and Freundlich isotherm models have been investigated. Pseudo-first order, pseudo-second order and modified pseudo-first order kinetic models have been used for experimental data. The results showed that removal efficiency was increased with increasing of adsorbent dosage, contact time and decreasing of $\mathrm{pH}$, but with increasing of dye concentration, the removal efficiency was decreased. Adsorption isotherm models showed that Langmuir isotherm model was best fitted onto collected data $\left(r^{2}>0.978\right)$. In addition, kinetic models showed that sorption of AR18 onto activated carbon prepared from poplar wood follows the pseudo-first order model $\left(\mathrm{r}^{2}>0.9758\right)$.
\end{abstract}

Keywords: Poplar wood, Activated carbon, Dye sorption, Kinetics study, Isotherm.

\section{Introduction}

Textile industries generate highly colored wastewaters that bearing organic and inorganic pollutants, so removal of dyes from these industries is an important practice due to its pollution of environment ${ }^{1}$. Azo dyes are one of the synthetic dyes that used in many textile 
Industries $^{2}$. Azo dye have an azo group band $(-\mathrm{N}=\mathrm{N}-)$ and because of their low cost, solubility and stability, are widely used in many textile industries. Azo dye and their intermediate products are toxic, carcinogenic and mutagenic to aquatic life $\mathrm{f}^{3,4}$. Several methods such as adsorption ${ }^{5,6}$, coagulation and flocculation ${ }^{7}$, biological treatment ${ }^{8,9}$, advanced oxidation processes $^{10}$, photocatalytic process ${ }^{11}$ have been used for treatment of colored wastewater. Removal of dye from colored effluents by adsorption processes has been to be an efficient and economical $^{12}$. Commercial activated carbon is a most popular adsorbent but is expensive. For that reason, researchers investigate production of activated carbon from low cost material such as Guava Seed ${ }^{13}$, bituminous coal ${ }^{14}$, olive-waste cakes ${ }^{15}$, waste biomass ${ }^{16}$ and so on.

In this work, we investigate the preparation of activated carbon from poplar wood, which can be found in many places of Iran, and examined its efficiency for removal of an azo dye AR18 from aquatic solution. The main aim of present work is as the following:

- Preparation of activated carbon from poplar wood by chemical activation

- Investigation of several parameters such as $\mathrm{pH}$ of dye solution, contact time, initial dye concentration and activated carbon dosage

- Fitting of the experimental data onto Langmuir and Ferundlich isotherm models

- Fitting of the experimental data onto pseudo-first order, pseudo-second order and modified pseudo-first order kinetic models

\section{Experimental}

Activated carbon can be prepared by tow distinct methods, namely chemical activation and physical activation. In physical activation, initial material carbonized in absence of oxygen and then the carbonized material activated by using of $\mathrm{H}_{2} \mathrm{O}, \mathrm{O}_{2}$ and $\mathrm{CO}_{2}$. In chemical activation, the raw material impregnated by an activation agent, such as $\mathrm{KoH}, \mathrm{H}_{2} \mathrm{SO}_{4}$, $\mathrm{H}_{2} \mathrm{PO}_{4}, \mathrm{ZnCl}_{2}$ and heated at $400-1000{ }^{\circ} \mathrm{C}$ for one hour ${ }^{13,14,17}$. In this work, we have prepared activated carbon by chemical method. A given amount of crushed poplar wood impregnated with phosphoric acid as an activation agent and then heated in $700-900{ }^{\circ} \mathrm{C}$ for one hour. After that, char particles washed in distillated water for four to five times and dried in oven for tow hours at $120{ }^{\circ} \mathrm{C}$. The activated screened by 40 mesh sieve and was used as adsorbent.

In this study various parameters that were studied in this work are $\mathrm{pH}$ (ranges from 5 to11), initial dye concentration $(25,50,75$ and $100 \mathrm{mg} / \mathrm{L})$, initial adsorbent dosage (0.6, 0.8 and $1 \mathrm{~g}$ ) and contact time (ranges from 30 to 120 minute). The dye (Merck, Germany) that used in this study was highly purity and used without any purification. Figure 1 show the structure of AR18. Solution of $1 \mathrm{~N} \mathrm{NaOH}$ and $\mathrm{H}_{2} \mathrm{SO}_{4}$ (Merck, Germany) was used for adjusting of $\mathrm{pH}$. All experiments was conducted in a batch system. For experiments, a given amount of prepared activated carbon was added to $200 \mathrm{~mL}$ of dye solution in various $\mathrm{pH}$ and stirred (Hanna-Hi 190M, Singapore) in $200 \mathrm{rpm}$ and then in the given time interval, the solution was centrifuged and final concentration of dye is was determined using a UV/VIS spectrophotometer (Model 1700, Shimadzu, Japan) at the maximum wavelength of $506 \mathrm{~nm}$.

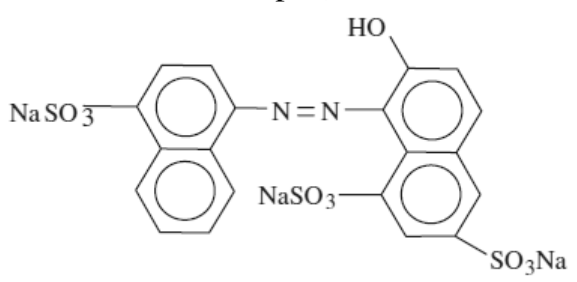

Figure 1. Chemical structure of AR18. 


\section{Results and Discussion}

\section{Effect of $p H$ on dye adsorption}

Generally, in adsorption processes, the $\mathrm{pH}$ plays an important role ${ }^{15}$. The effect of $\mathrm{pH}$ on the adsorption of AR18 is shown on Figure 2. From the figure, it was observed that dye sorption decreased with the increasing of $\mathrm{pH}$ solution. In low $\mathrm{pH}$ the surface of activated carbon charged with $\mathrm{H}^{+}$ion and this leads to significantly strong electrostatic attraction between the positively charged carbon surface and anionic dye molecule that cause increasing of dye sorption ${ }^{15}$. Also by increasing of $\mathrm{pH}$ solution, the number of negatively charged sites on the surface of activated carbon increased. On the other hand the number of the positively charged sites decreased. Activated carbon with negatively charged sites due to electrostatic repulsion can not adsorb the anionic dye, therefore by increasing of $\mathrm{pH}$, dye removal would been decreased ${ }^{12,16}$.

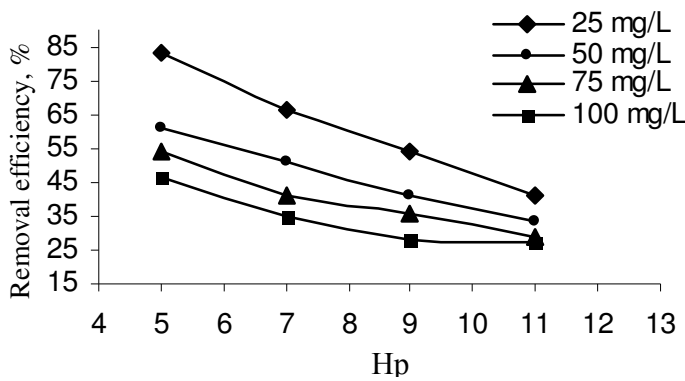

Figure 2. Effect of $\mathrm{pH}$ on dye removal in different dye concentration (contact time $=1 \mathrm{~h}$, adsorbent dosage $=0.8 \mathrm{~g}$ )

\section{Effect of adsorbent dosage}

Adsorption capacity can be increased by increasing of adsorbent dosage ${ }^{10}$. The test for investigation of effect of adsorbent dosage carried out by keeping all of other parameter constant. The effect of adsorbent dosage on dye sorption is shown in Figure 3. As shown in this figure, by increasing of adsorbent mass, dye sorption was increased. Also in $\mathrm{pH}=7$, by increasing of adsorbent mass from 0.6 to $1 \mathrm{~g}$, removal of dye increased from $35 \%$ to $58 \%$.

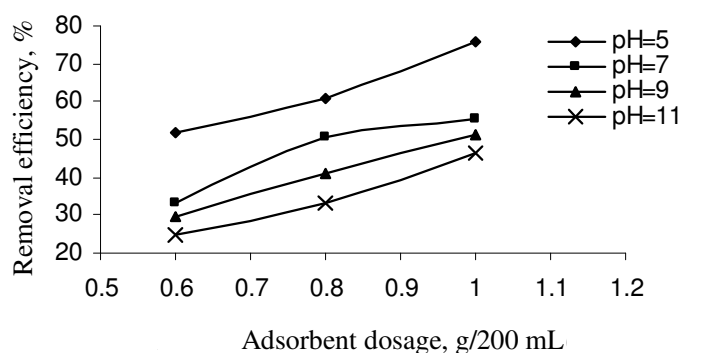

Figure 3. Effect of adsorbent dosage on dye removal in different $\mathrm{pH}$ (contact time $=1 \mathrm{~h}$, dye solution of $50 \mathrm{mg} / \mathrm{L}$ ).

\section{Effect of initial dye concentration}

Studies for investigation of the effect of dye concentration on dye removal carried out by adding of $0.6 \mathrm{~g}$ prepared activated carbon in $200 \mathrm{~mL}$ dye solution and contact time equal $1 \mathrm{~h}$. Figure 4 shows the effect of initial dye concentration on the adsorption of dye. As shown on this figure, by increasing of initial dye concentration, removal of dye was decreased. 


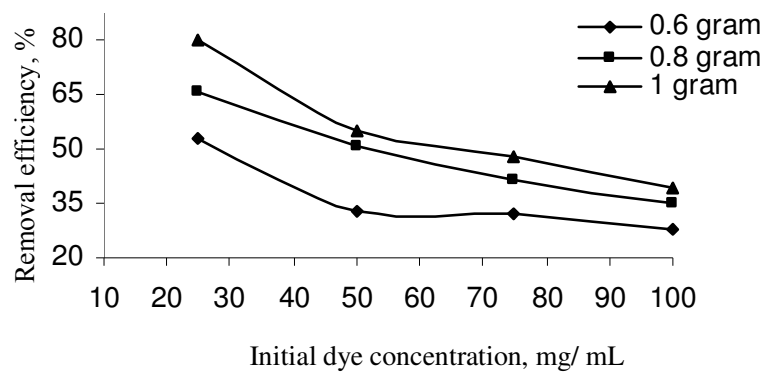

Figure 4. Effect of initial dye concentration on dye removal ( $\mathrm{pH}=7$, contact time $=1 \mathrm{~h}$ ).

\section{Effect of contact time}

Dye solution of $50 \mathrm{mg} / \mathrm{L}$ was performed to analyze the effect of contact time. The effect of contact time on dye removal is shown on Figure 5. As shown in Figure 5, by increasing of contact time, removal of dye was increased. In addition, removal of dye at the initial period of contact time was found to be rapid and then by increasing of contact time, adsorption of dye become slowly and reached to equilibrium at 120 minute.

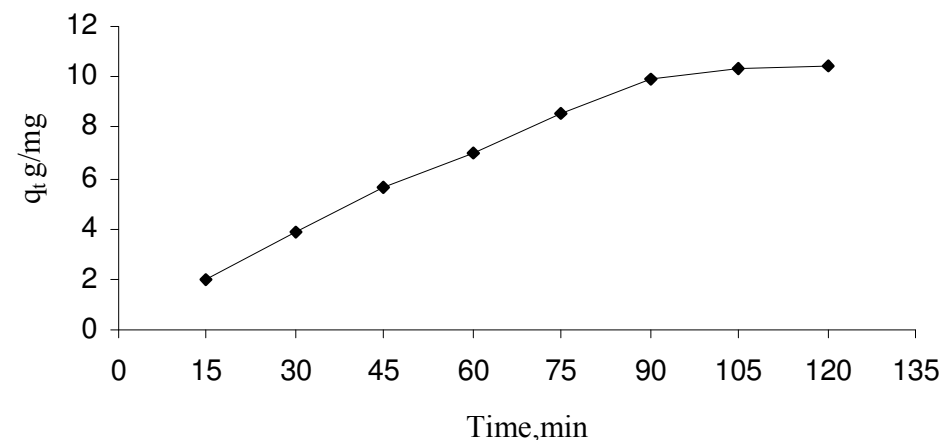

Figure 5. Effect of contact time on dye removal $(\mathrm{pH}=7$, adsorbent dosage $=0.8 \mathrm{~g}$, dye solution $=50 \mathrm{mg} / \mathrm{L}$ ).

\section{Adsorption isotherm}

Adsorption isotherm describes the relationship between the equilibrium amount of solute adsorbed on adsorbent and the amount of remaining solute. Langmuir and Freundlich isotherm models are commonly used for description of adsorption process.

\section{Freundlich equation}

The non linear form of Freundlich equation is expressed as the following:

$$
q_{e}=k_{f} C_{e}^{1 / n}
$$

Where $\mathrm{q}_{\mathrm{e}}$ is the amount of adsorbate $(\mathrm{mg} / \mathrm{g}), \mathrm{C}_{\mathrm{e}}$ is the equilibrium concentration of adsorbate $\left(\mathrm{mgL}^{-1}\right), \mathrm{k}_{\mathrm{f}}$ and $1 / \mathrm{n}$ are the Freundlich constants. The linear form of Eq. 1 is as the following:

$$
\log \left(q_{e}\right)=\log k_{f}+1 / n \log \left(C_{e}\right)
$$

Freundilch constants can be determined from the slope and intercept of linear plots of $\log \mathrm{q}_{\mathrm{e}} v s . \log \mathrm{C}_{\mathrm{e}}$, respectively. Figure 6 shows the plot of $\log \mathrm{q}_{\mathrm{e}} v s . \log \mathrm{C}_{\mathrm{e}}$ for present study. 


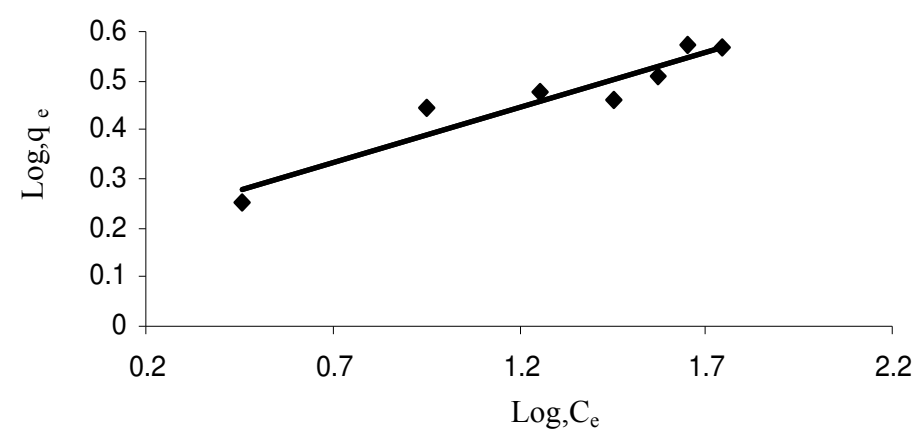

Figure 6. Langmuir isotherm model for present system ( $\mathrm{V}=200 \mathrm{~mL}$, Adsorbent dosage $=0.8 \mathrm{~g}$, $\mathrm{pH}=7, \mathrm{~T}=20^{\circ} \mathrm{C}$, Contact time $=3$ day).

\section{Langmuir equation}

Langmuir isotherm model which commonly used for monolayer adsorption is described as follow:

$$
q_{e}=\frac{q_{m} b C_{e}}{1+b C_{e}}
$$

Where $\mathrm{q}_{\mathrm{e}}$ is the amount of adsorbate $(\mathrm{mg} / \mathrm{g}), \mathrm{C}_{\mathrm{e}}$ is the equilibrium concentration of adsorbate $(\mathrm{mg} / \mathrm{L}), \mathrm{q}_{\mathrm{m}}$ the maximum adsorption capacity and $\mathrm{b}$ is the langmuir constant. The linear form of the Langmuir equation is as the following:

$$
\frac{C_{e}}{q_{e}}=\frac{C_{e}}{q_{m}}+\frac{1}{q_{m} b}
$$

$\mathrm{q}_{\mathrm{m}}$ and $\mathrm{b}$ can be calculated from the slope and intercept of plots of $\mathrm{C}_{\mathrm{e}} / \mathrm{q}_{\mathrm{e}} v s$. $\mathrm{C}_{\mathrm{e}}$. Figure 7 shows the plot of $\log \left(\mathrm{q}_{\mathrm{e}}\right)$ vs. $\log \left(\mathrm{C}_{\mathrm{e}}\right)$ for present system. Table 1 shows the parameters of isotherm model. It is clear from this Table, the sorption of AR18 follows Langmuir isotherm model.

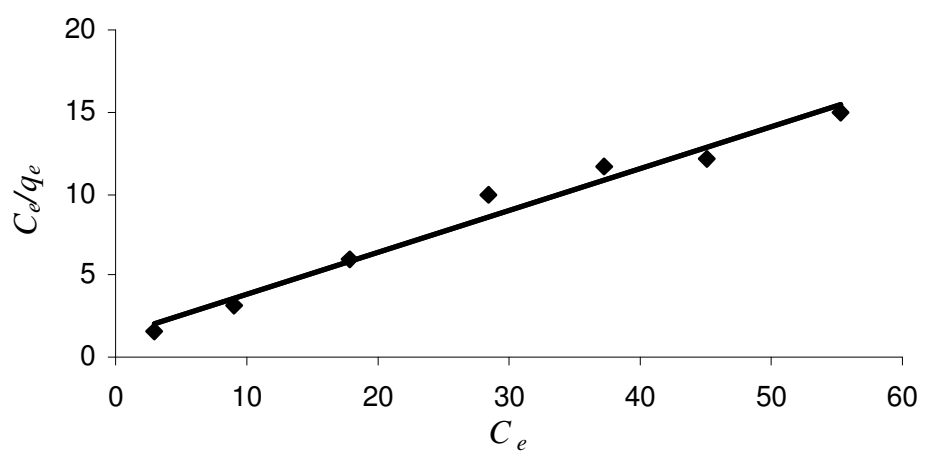

Figure 7. Langmuir isotherm model for present system $(\mathrm{V}=200 \mathrm{~mL}$, Adsorbent dosage $=0.8 \mathrm{~g}$, $\mathrm{pH}=7, \mathrm{~T}=20^{\circ} \mathrm{C}$, Contact time $=3$ days)

Table 1. Parameters of Freundlich and Langmuir Isotherm model.

\begin{tabular}{lccccc}
\hline & $\mathrm{q}_{\mathrm{m}}, \mathrm{mg} / \mathrm{g}$ & $\mathrm{b}, \mathrm{L} / \mathrm{mg}$ & $\mathrm{k}_{\mathrm{f}}$ & $\mathrm{n}$ & $\mathrm{R}^{2}$ \\
\hline Freundlich & - & - & 1.5062 & 4.468 & 0.903 \\
Langmuir & 3.9108 & 0.1933 & - & - & 0.978 \\
\hline
\end{tabular}




\section{Kinetic Models}

\section{Pseudo-first order kinetic}

Pseudo-first order kinetic is described by the following equation ${ }^{18}$ :

$$
\frac{d q_{t}}{d_{t}}=k_{1}\left(q_{e}-q_{t}\right)
$$

Where $\mathrm{q}_{\mathrm{e}}$ and $\mathrm{q}_{\mathrm{t}}$ are the amounts (mg/g) of adsorbate at equilibrium and at time $\mathrm{t}(\mathrm{min})$ respectively; and $\mathrm{k}_{1}$ is the constant rate $(1 / \mathrm{min})$. Integration of the Eq. (5) at the boundary of $\mathrm{q}_{\mathrm{t}}=0$ at $\mathrm{t}=0$ and $\mathrm{q}_{\mathrm{t}}=\mathrm{q}_{\mathrm{t}}$ at $\mathrm{t}=\mathrm{t}$, the equation of (5) can be converted to the linear form as the following equation:

$$
\log \left(1-q_{t} / q_{e}\right)=-\frac{k_{1}}{2.303} t
$$

Figure 8 shows the pseudo-first order curve for experimental data.

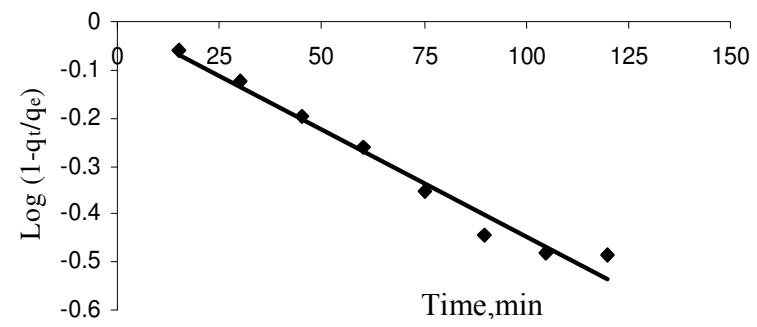

Figure 8. Pseudo-first order model for present system.

\section{Pseudo-second order kinetic}

Pseudo-second order kinetic is expressed as the following equation ${ }^{18}$ :

$$
\frac{d q_{t}}{d t}=k_{2}(q e-q t)^{2}
$$

Where $\mathrm{q}_{\mathrm{e}}$ and $\mathrm{q}_{\mathrm{t}}$ are the amounts $(\mathrm{mg} / \mathrm{g}$ ) of adsorbate at equilibrium and at time $\mathrm{t}(\mathrm{min})$ respectively; and $\mathrm{k}_{2}$ is the constant rate $(\mathrm{g} / \mathrm{mg} \mathrm{min})$. Integration of the Eq. (7) at the boundary of $\mathrm{q}_{\mathrm{t}}=0$ at $\mathrm{t}=0$ and $\mathrm{q}_{\mathrm{t}}=\mathrm{q}_{\mathrm{t}}$ at $\mathrm{t}=\mathrm{t}$, the equation of (7) can be converted to the linear form as follows:

$$
\frac{t}{q_{t}}=\frac{1}{k_{2} q_{e}{ }^{2}}+\frac{1}{q_{e}} t
$$

The value of $\mathrm{k}_{2}$ and $\mathrm{q}_{\mathrm{e}}$ can be determined from the slope and intercept of the plot $\mathrm{t} / \mathrm{q}_{\mathrm{t}} v s$. $\mathrm{t}$, respectively. Figure 9 shows the pseudo-second order model curve for experimental data.

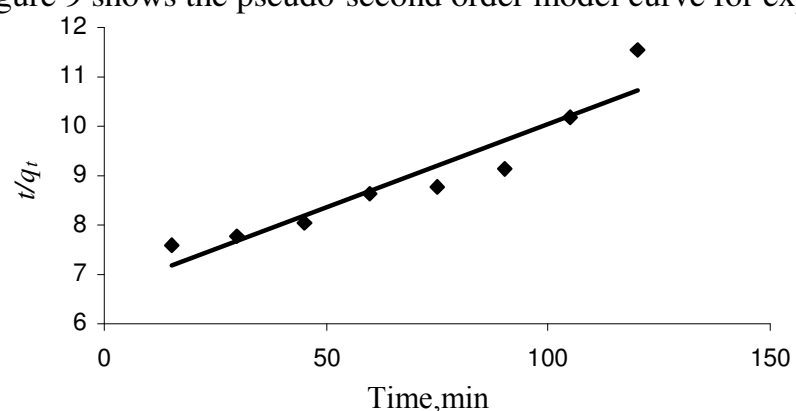

Figure 9. Pseudo-second order model for the collected data. 


\section{Modified Pseudo-first order}

Modified pseudo-first order model empirically was proposed by Yang and Al-Dury ${ }^{19}$ and then modified theoretically by Azizian and Bashiri ${ }^{20}$ is expressed as the following:

$$
\frac{d q_{t}}{d r}=k_{m} \frac{q_{e}}{q_{t}}\left(q_{e}-q_{t}\right)
$$

By integration of Eq. (9) at the boundary of $\mathrm{q}_{\mathrm{t}}=0$ at $\mathrm{t}=0$ and $\mathrm{q}_{\mathrm{t}}=\mathrm{q}_{\mathrm{t}}$ at $\mathrm{t}=\mathrm{t}$, the following equation will be derived:

$$
\operatorname{Ln}\left(1-q_{t} / q_{e}\right)+q_{t} / q_{e}=-k_{m} t
$$

$\mathrm{k}_{\mathrm{m}}$ can be obtained from the slop of plots of $\ln \left(1-\mathrm{q}_{\mathrm{t}} / \mathrm{q}_{\mathrm{e}}\right)+\mathrm{q}_{\mathrm{t}} / \mathrm{q}_{\mathrm{e}} v s$. t. Figure 10 shows the modified pseudo-first order model curve for present system.

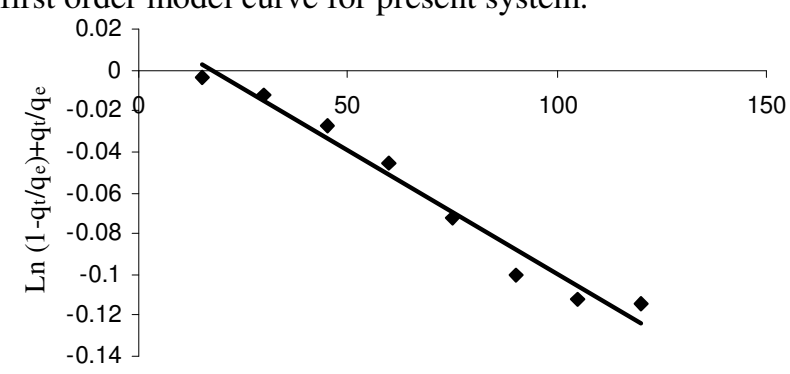

Time, $\min$

Figure 10. Shows the modified pseudo-first order model for present system.

Table 2 shows the parameters of kinetic models. The conformity of experimental data with the pseudo-first order, pseudo-second order and modified pseudo-first order models can be determined by the correlation coefficient $\left(\mathrm{R}^{2}\right)$. It is clear from Table 2 that pseudo-first order best describe sorption of AR18 onto activated carbon derived from Poplar wood.

Table 2. Parameters of kinetic models.

\begin{tabular}{lccccl}
\hline \multicolumn{1}{c}{ Model } & $\mathrm{k}_{1}$ & $\mathrm{k}_{2}$ & $\mathrm{k}_{\mathrm{m}}$ & $\mathrm{q}_{\mathrm{e}}$ & $\mathrm{R}^{2}$ \\
\hline Pseudo-first order model & 0.01013 & - & - & 15.435 & 0.9758 \\
Pseudo-second order model & - & $1.736 \times 10^{-4}$ & - & 29.41 & 0.8858 \\
Modified pseudo-first order & - & - & 0.0012 & 25.7 & 0.9706 \\
\hline
\end{tabular}

\section{Conclusion}

In this study the adsorption of AR18 on activated carbon derived from poplar wood was investigated. Influence of parameters such as $\mathrm{pH}$, initial dye concentration, adsorbent mass and contact time on removal efficiency were studied. The result showed that by increasing of adsorbent mass and contact time, sorption of dye was increased. Also removal of dye found to be decreased by increasing of $\mathrm{pH}$ and initial dye concentration. Adsorption isotherm models showed that Langmuir isotherm model was best fitted onto collected data $\left(r^{2}>0.978\right)$. In addition, kinetic models showed that sorption of AR18 onto activated carbon prepared from Poplar Wood follows the pseudo-first order model.

\section{References}

1. Atia A A, Donia A M and Al-Amrani W A, Chem Eng J., 2009, 150(1), 55-62.

2. Garcia J C, Simionato J I, Carli da Silva A E, Nozaki J and N Evelázio de Souza, Solar Energy, 2009, 83(3), 316-22. 
3. Kasiri M B, Aleboyeh H and Aleboyeh A, Appl Catal B: Environ., 2008, 84, 9-15.

4. Renganathan S, Thilagaraj W R, Miranda L R, Gautam P and Velan M, Biores Technol., 2006, 97, 2189-2193.

5. Kuo C-Y, Wu C-H and Wu J-Y, J Colloid Interface Sci., 2008, 327, 308-315.

6. Karaca S, Gurses A, Acikyidiz M and Ejder (Korucu) M, Microporous and Mesoporous Materials, 2008, 115, 376-82.

7. Rahbar M S, E A and Sedighi R E, J Environ Sci Technol., 2006, 3, 79-88.

8. Tan N C, Borger A, Slenders P, Svitelskaya A, Lettinga G and Field J A, Water Sci Tech., 2000, 42, 337-344.

9. Mendez-Paz D, Omil F and Lema J M, Enzyme and Microbial Technology, 2005, 36, 264-272.

10. Azbar N, Yonar T and Kestioglu K, Chemosphere, 2004, 55, 35-44.

11. Mozia S, Tomaszewska M and Morawski A W, Desalination, 2005, 185, 449-456.

12. Janso P, Buchtova H and Ryznarova M, Water Res., 2003, 37, 4938-4944.

13. Joseph C G, Bono A, Krishnaiah D and Soon K O, Materials Science (Medžiagotyra), 2007, 13, 83-87.

14. Cuhadaroglu D and Uygun O A, Afr J Biotechnol., 2008, 7, 3703-3710.

15. Baccar R, Bouzid J, Feki M and Montiel A, J Hazard Mater., 2009, 162, 1522-1529.

16. Nunes A A, Franca A S and Oliveira L S, Biores Technol., 2009, 100, 1768-1792.

17. Demirbas E, Kobya M and Sulak M T, Biores Technol., 2008, 99, 5368-5373.

18. Azizian S, J Colloid Interface Sci., 2004, 276, 47-52.

19. Yang X, Al-Duri, J Colloid Interface Sci., 2005, 287, 25-34.

20. Azizian S and Bashiri H, Langmuir, 2008, 24, 11669-11676. 


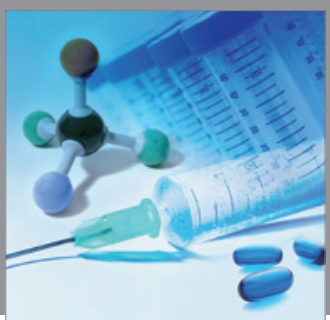

International Journal of

Medicinal Chemistry

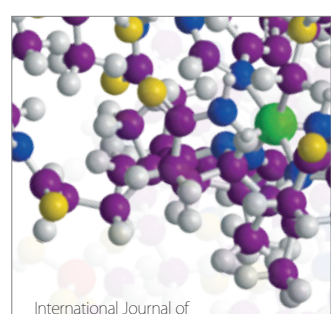

Carbohydrate Chemistry

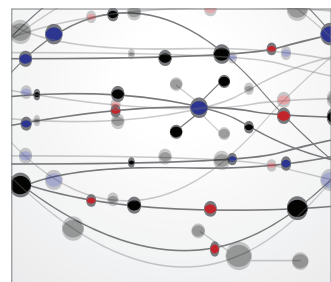

The Scientific World Journal
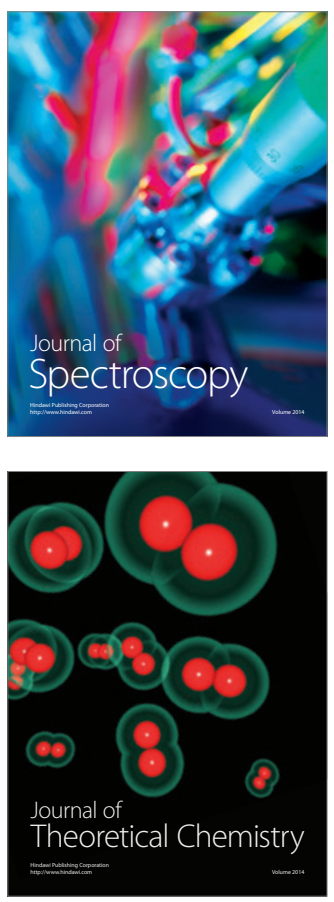
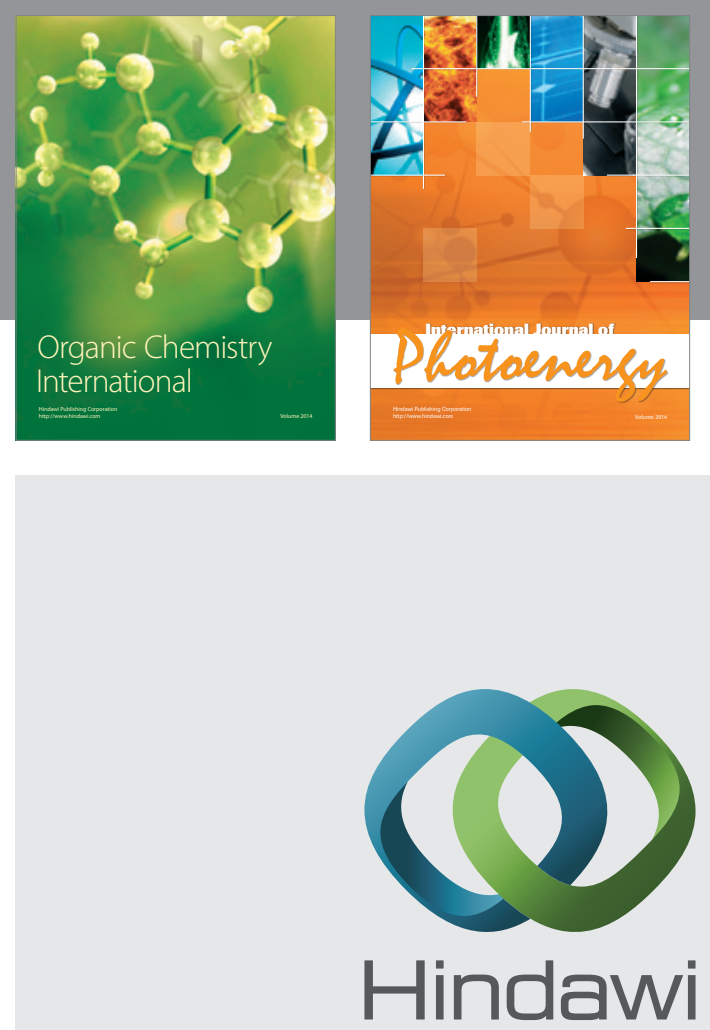

Submit your manuscripts at

http://www.hindawi.com
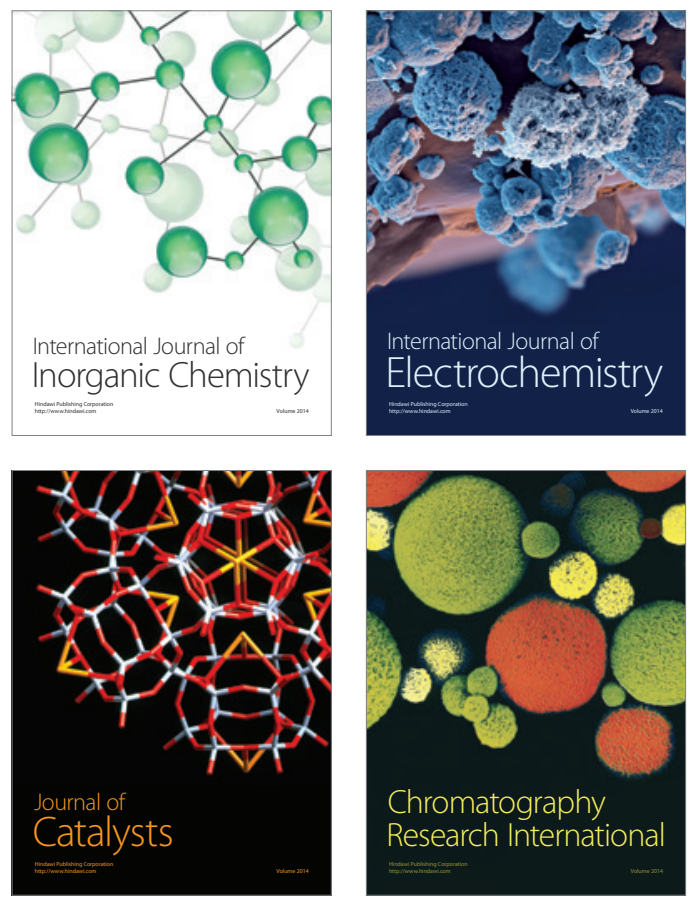
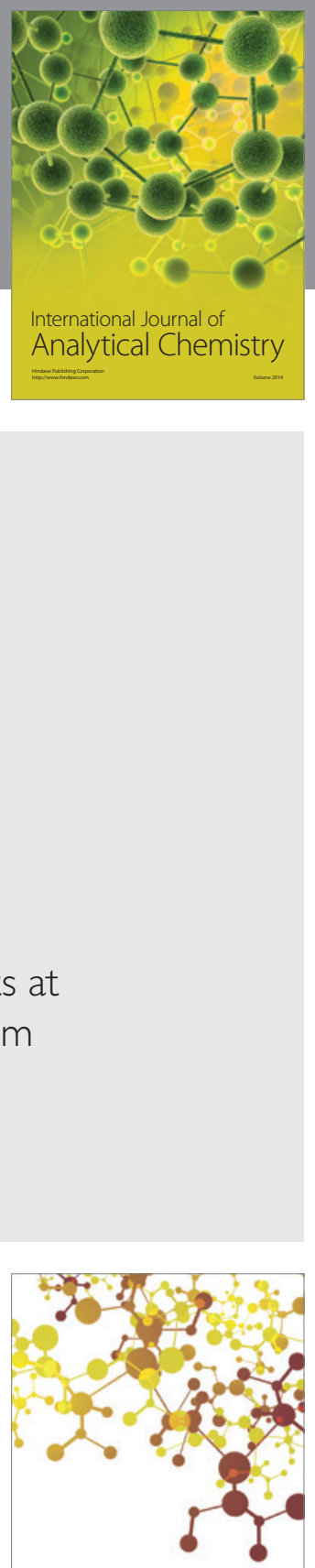

Journal of

Applied Chemistry
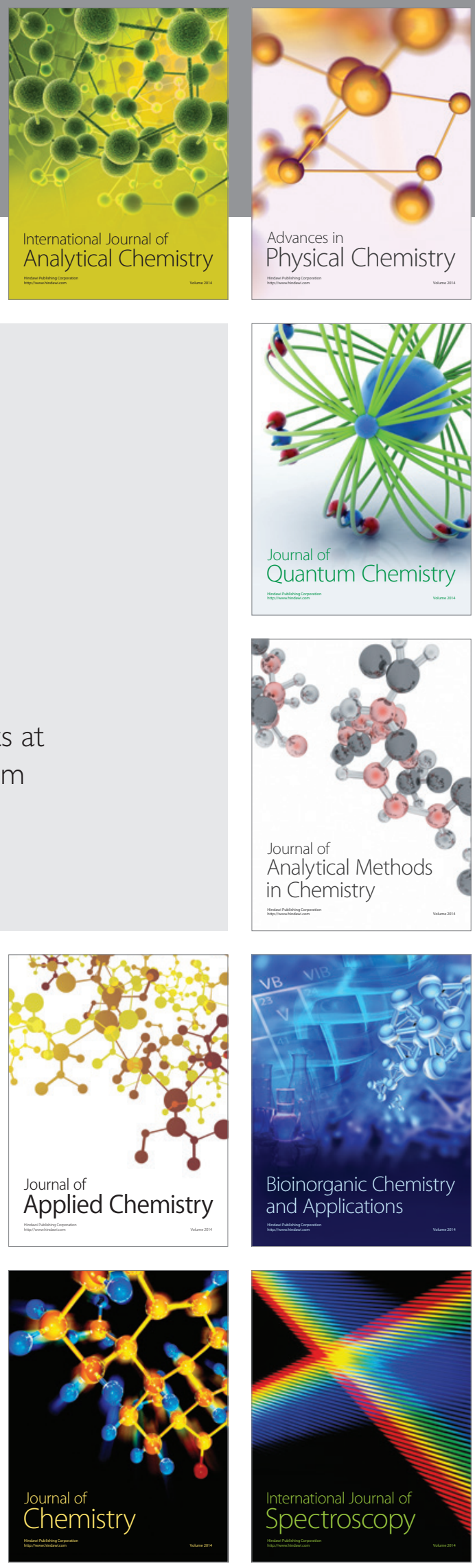